\title{
ANALISIS RISIKO BENCANA TANAH LONGSOR DI KECAMATAN SUKASADA, KABUPATEN BULELENG
}

\author{
I Wayan Gede Eka Saputra ${ }^{1 *)}$, I.P.G. Ardhana ${ }^{2)}$, I Wayan Sandi Adnyana ${ }^{3)}$ \\ 1) UPT Pusdalops PB BPBD Provinsi Bali \\ 2)Jurusan Biologi Fakultas MIPA Universitas Udayana \\ 3)Jurusan Agroekoteknologi Fakultas Pertanian Universitas Udayana \\ ${ }^{*}$ Email :iwayangedeekasaputra@gmail.com
}

\begin{abstract}
Sukasada Sub-District is a region that is largely a hilly area with steep slopes, rainfall intensity is high enough and unstable ground conditions. This leads that the Sub-District of Sukasada becomes potential for the occurrence of landslides. Mitigation effort is therefore necessary to reduce the risk of landslides that may occur. The purpose of this study was to determine the level of threats, vulnerabilities and capacities of level landslides in Sub-District of Sukasada. In addition to the above objectives, the study also aims to formulate strategies for disaster risk reduction of landslides in the Sub-District of Sukasada.

The results showed the threat of landslides in the Sub-District of Sukasada is covering 11.169 hectares or $69,51 \%$ of the total area. High threat level area is around 727 hectares, the threat level is covering 7.717 hectares and a low threat level area is around 2.725 hectares. The level of vulnerability of landslides in SubDistrict of Sukasada ranges from moderate to high. The highest vulnerability level (0.83) is located in some villages, such as: Pancasari, Pegayaman, Panji and Panji Anom Village. While the lowest level of vulnerability (0.66) is in Padangbulia Village. The level of local capacity to landslides in the Sub-District of Sukasada is low, with the resistance area index of 40,25 or capacity level of 0,2349. The level of risk of landslides in the Sub-District of Sukasada is classified as moderate to high. Areas with moderate risk levels are covering 2.032 hectares and a high level of risk covering 7.171 hectares. Strategies that can be done to cope with disaster risk are to reduce the threat, reduce vulnerability and increase capacity. Areas with moderate risk level can be done non-structural mitigation. Structural mitigation can be done in areas with a high level of risk.
\end{abstract}

Keywords: landslides; threats; vulnerability; capacity; risk.

\section{PENDAHULUAN}

Indonesia merupakan wilayah yang rawan terhadap berbagai jenis bencana. Bencana menyebabkan kerusakan dan kehancuran. Menurut Undang-Undang Nomor 24 Tahun 2007, bencana adalah peristiwa atau rangkaian peristiwa yang mengancam dan mengganggu kehidupan dan penghidupan masyarakat yang disebabkan, baik oleh faktor alam dan atau faktor non alam maupun faktor manusia sehingga mengakibatkan timbulnya korban jiwa manusia, kerusakan lingkungan, kerugian harta benda, dan dampak psikologis.

Bencana tanah longsor adalah salah satu bencana yang sering menelan korban jiwa, kerugianhartabenda dan menimbulkan kerusakan saranadan prasarana yang dapat berdampak pada kondisi ekonomi dan sosial. Tanah longsor adalah perpindahan material pembentuk lereng berupa batuan, bahan rombakan, tanah, material campuran tersebut bergerak ke bawah atau keluar lereng. Faktor utama penyebab terjadinya tanah longsor adalah : jenis tanah pada lapisan atas permukaan (top soil), vegetasi penutup, kemiringan lereng, dan tinggi rendahnya curah hujan.Menurut Subowo
(2003), ada enam jenis tanah longsor, yaitu:longsoran translasi, longsoran rotasi, pergerakan blok, runtuhan batu, rayapantanah, dan aliran bahan rombakan. Dari keenam jenislongsor tersebut, jenis longsor translasi dan rotasi paling banyak terjadi di Indonesia.

Menurut Bappeda Bali dan PPLH Universitas Udayana (2006), potensi bencana tanah longsor di Provinsi Bali seluas 85.121,55 ha. Salah satu kabupaten yang rawan terhadap bencana tanah longsor adalah Kabupaten Buleleng. Wilayah-wilayah rawan tanah longsor di Buleleng antara lain terdapat di Kecamatan Gerokgak, Busungbiu, Sukasada, dan Tejakula.

Hasil penelitian yang dilakukan oleh Dinata et al. (2013) berupa peta daerah rawan bencana longsor di Kecamatan Sukasada menunjukkan bahwa Kecamatan Sukasada memiliki potensi kerawanan untuk terjadinya bencana longsor.Peta ancaman bencana gerakan tanah dari Kementerian Energi dan Sumberdaya Mineral Republik Indonesia, menunjukkan wilayah Kecamatan Sukasada memiliki potensi kerawanan menengah sampai tinggi untuk terjadinya bencana tanah longsor. Beberapa kejadian bencana tanah longsor di Kecamatan Sukasada 
:tanah longsor di Desa Pancasari pada 2 Pebruari 2012 menyebabkan 2 orang meninggal, 1 orang luka, 1 rumah rusak, tanah longsor di Desa Gitgit 19 Pebruari 2013 menyebabkan 2 orang meninggal dunia, tanah longsor di Desa Sambangan 15 Desember 2013 menyebabkan 3 orang meninggal dunia dan tanah longsor di Desa Padangbulia 24 April 2014 menyebabkan tertimbunnya saluran irigasi dan badan jalan(BPBD Bali, 2014). Atas dasar hal tersebut maka perlu dilakukan penelitian mengenai analisis risiko bencana tanah longsor di Kecamatan Sukasada, Kabupaten Buleleng.

Tujuan dari penelitian ini adalah mengetahui tingkat ancaman, tingkat kerentanan dan tingkat kapasitas bencana tanah longsor di Kecamatan Sukasada. Selain tujuan diatas, penelitian ini juga bertujuan untuk merumuskan strategi pengurangan risiko bencana tanah longsor di Kecamatan Sukasada.

\section{METODOLOGI}

Penelitian ini dilakukan di Kecamatan Sukasada, Kabupaten Buleleng. Penelitian ini dilaksanakan pada bulan Desember 2014 sampai dengan bulan Mei 2015.Analisis risiko bencana tanah longsor berdasarkan Peraturan Kepala Badan Nasional Penanggulangan Bencana No. 2 Tahun 2012. Tingkat ancaman diperoleh dengan menumpangtindihkan peta potensi gerakan tanah dengan kemiringan lereng. Tingkat Kerentanan diperoleh dengan menumpangtindihkan kerentanan fisik, kerentanan sosial, kerentanan ekonomi dan kerentanan lingkungan. Komponen kerentanan fisik : jumlah rumah, jumlah fasilitas umum dan fasilitas kritis. Komponen kerentanan fisik : jumlah penduduk, penduduk miskin, penduduk cacat, penduduk usia rentan. Komponen ekonomi : lahan produktif dan Produk Domestik Regional Bruto (PDRB). Komponen kerentanan lingkungan : hutan, hutan bakau/mangrove dan semak belukar. Tingkat Kapasitas diperoleh dengan melakukan diskusi kelompok terfokus dengan instansi terkait. Data yang digunakan dalam penelitian ini adalah data primer dan data sekunder. Data primer yang diambil adalah data kapasitas Kecamatan Sukasada. Data sekunder yang diambil adalah peta potensi gerakan tanah diperoleh dari Badan Geologi dan ESDM, peta kemiringan dan dari Badan Informasi Geospasial (BIG), data jumlah rumah, fasilitas umum, data kependudukan, PDRB dari Badan Pusat Statistik (BPS) Kabupaten Buleleng, data penggunaan lahan dari Badan Perencanaan Pembangunan Daerah (Bappeda) Provinsi Bali

Peta risiko bencana disusun dengan melakukan overlay peta ancaman, peta kerentanan dan peta kapasitas.Ancaman (bahaya) dipetakan berdasarkan penyusunan beberapa parameter yang berpengaruh pada tiap-tiap jenis ancaman (bahaya). Masingmasing parameter memiliki nilai/skor yang akan menentukan tingkat ancaman menjadi rendah, sedang, dan tinggi (Perka BNPB No. 2 tahun 2012).

Analisis kerentanan dapat dilakukan berdasarkan aspek sosial, fisik, ekonomi, dan lingkungan yang dikelompokkan kedalam indeks penduduk terpapar dan indeks kerugian.Pengkajian kapasitas dihitung berdasarkan ketahanan daerah dalam penanggulangan kebencanaan. Nilai ketahanan suatu daerah diperoleh dari hasil focus group discussion (FGD)dengan Badan Penanggulangan Bencana Kabupaten Buleleng, Camat Sukasada dan seluruh kepala desa/perbekel Kecamatan Sukasada.

Tingkat ancaman tanah longsor diperoleh dari overlay peta gerakkan tanah dari Badan Geologi dan ESDM dan peta kemiringan dari Badan Informasi Geospasial. Indeks ancaman rendah memiliki skor 0 sampai 0,33 , indeks ancaman sedang memiliki skor 0,34 sampai 0,66 dan indeks ancaman tinggi memiliki skor 0,67 sampai 1,00.

Tingkat kerentanan bencana tanah longsor dipengaruhi oleh empat komponen, yaitu :

- Kerentanan fisik

kerentanan fisik $=(0,4 \mathrm{x}$ skor rumah $)+(0,3 \mathrm{x}$ skor fas. umum $)+(0,3 \times$ skr fas. kritis $)$

Tabel 1. Parameter kerentanan fisik

\begin{tabular}{|c|c|c|c|c|c|}
\hline \multirow{2}{*}{ Parameter } & \multirow{2}{*}{$\begin{array}{c}\text { Bobot } \\
(\%)\end{array}$} & \multicolumn{3}{|c|}{ Kelas } & \multirow{2}{*}{ Skor } \\
\hline & & Rendah & Sedang & Tinggi & \\
\hline Rumah & 40 & $<400 \mathrm{jt}$ & $400-800$ jt & $>800 \mathrm{jt}$ & Kelas Nilai \\
\hline Fasilitas umum & 30 & $<500 \mathrm{jt}$ & 500 jt - $1 \mathrm{M}$ & $>1 \mathrm{M}$ & Max Kelas \\
\hline Fasilitas kritis & 30 & $<500 \mathrm{jt}$ & 500 jt - $1 \mathrm{M}$ & $>1 \mathrm{M}$ & \\
\hline
\end{tabular}

- Kerentanan Sosial

kerentanan sosial $=0,6 \times \frac{\log \left(\frac{\text { kepadatan penduduk }}{0,01}\right)}{\log \left(\frac{100}{0,01}\right)}$

$+(0,1 \times$ rasio jenis kelamin $)+(0,1 \times$ rasio kemiskinan $)+(0,1 \mathrm{x}$ rasio orang cacat $)+(0,1 \mathrm{x}$ rasio umur rentan)

Tabel 2. Parameter kerentanan sosial

\begin{tabular}{|c|c|c|c|c|c|}
\hline \multirow{2}{*}{ Parameter } & \multirow{2}{*}{$\begin{array}{c}\text { Bobot } \\
(\%)\end{array}$} & \multicolumn{3}{|c|}{ Kelas } & \multirow{2}{*}{ Skor } \\
\hline & & Rendah & Sedang & Tinggi & \\
\hline Kepadatan penduduk & 60 & $\begin{array}{c}<500 \\
\text { jiwa/km² }\end{array}$ & $\begin{array}{c}500-100 \\
\text { jiwa/km² }\end{array}$ & $\begin{array}{c}>1000 \\
\text { jiwa/km² }\end{array}$ & $\begin{array}{l}\text { Kelas/Nilai } \\
\text { Max Kelas }\end{array}$ \\
\hline $\begin{array}{l}\text { Rasio jenis } \\
\text { kelamis (10\%) }\end{array}$ & 40 & $<20 \%$ & $20-40 \%$ & $>40 \%$ & \\
\hline \multicolumn{6}{|c|}{ Rasio Kemisikinan (10\%) } \\
\hline \multicolumn{6}{|c|}{ Rasio orang cacat (10\%) } \\
\hline \multicolumn{6}{|c|}{ Rasio kelompok umur (10\%) } \\
\hline
\end{tabular}


- Kerentanan Ekonomi

kerentanan ekonomi $=(0,6 \mathrm{x}$ skor lahan produktif $)+(0,4 \mathrm{x}$ PDRB $)$

Tabel 3. Parameter kerentanan ekonomi

\begin{tabular}{llllll}
\hline & & \multicolumn{3}{c}{ Kelas } & Skor \\
\cline { 3 - 4 } Parameter & Bobot $(\%)$ & Rendah & Sedang & Tinggi & Kelas Nilai Max Kelas \\
\hline Lahan produktif & 60 & $<50 \mathrm{jt}$ & $50-200 \mathrm{jt}$ & $>200 \mathrm{jt}$ & \\
PDRB & 40 & $<100 \mathrm{jt}$ & $100-300 \mathrm{jt}$ & $>300 \mathrm{jt}$ & \\
\hline
\end{tabular}

- Kerentanan Lingkungan

kerentanan lingkungan $=(0,8 \mathrm{x}$ skor hutan tanaman $)+(0,1$ skor hutan bakau $)+(0,1 \mathrm{x}$ skor semak belukar)

Tabel 4.Parameter kerentanan lingkungan

\begin{tabular}{|c|c|c|c|c|c|}
\hline \multirow{2}{*}{ Parameter } & \multirow{2}{*}{ Bobot $(\%)$} & \multicolumn{3}{|c|}{ Kelas } & \multirow{2}{*}{ Skor } \\
\hline & & Rendah & Sedang & Tinggi & \\
\hline Hutan tanaman & 80 & $<20$ ha & $20-50$ ha & $>50$ ha & Kelas Nilai Max Kelas \\
\hline Hutan Bakau/mangrove & 10 & $<10$ ha & $10-30$ ha & $>30$ ha & \\
\hline Semak belukar & 10 & $<10$ ha & $10-30$ ha & $>30$ ha & \\
\hline
\end{tabular}

- Tingkat Kerentanan

Kerentanan $+(0,4 \mathrm{x}$ skor kerentenan sosial $)+(0,25 \mathrm{x}$ skor kerentanan ekonomi $)+(0,25 \mathrm{x}$ skor kerentanan fisik $)+(0,1 \mathrm{x}$ skor kerentenan lingkungan $)$

Tingkat kapasitas diperoleh dari hasil diskusi kelompok terfokus (focuss group disscussion /FGD) dengan materi pengkajian kapasitas daerah berdasarkan Kerangka Aksi Hyogo. Parameter yang dinilai dalam indeks kapasitas : aturan dan kelembagaan penanggulangan bencana, peringatan dini dan kajian risiko bencana, pendidikan kebencanaan, pengurangan faktor risiko dasar dan pembangunan kesiapsiagaan pada seluruh lini.

Tingkat risiko bencana didasari pada adanya intensitas dan potensi ancaman dan mempertimbangkan potensi kerugian dan kapasitas penanggulangan bencana. Nilai risiko bencana suatu daerah dapat diperoleh dengan persamaan :

Risiko Bencana=Ancaman $\mathrm{x}$ Kerentanan/Kapasitas

\section{HASIL DAN PEMBAHASAN}

\subsection{Analisis Ancaman}

Daerah yang berbahaya untuk terjadinya bencana tanah longsor adalah daerah dengan kemiringan lereng $>15 \%$ (diatas $\left.8.51^{\circ}\right)$.Dari Peta Bahaya Tanah Longsor di Kecamatan Sukasada dapat diketahuiluas wilayah bahaya bencana tanah longsor di Kecamatan Sukasada adalah 11.169 hektar atau $69,51 \%$ dari luas wilayah Kecamatan Sukasada.
Peta Bahaya Tanah Longsor di Kecamatan Sukasada dapat dilihat pada Gambar 1.Jumlah penduduk yang

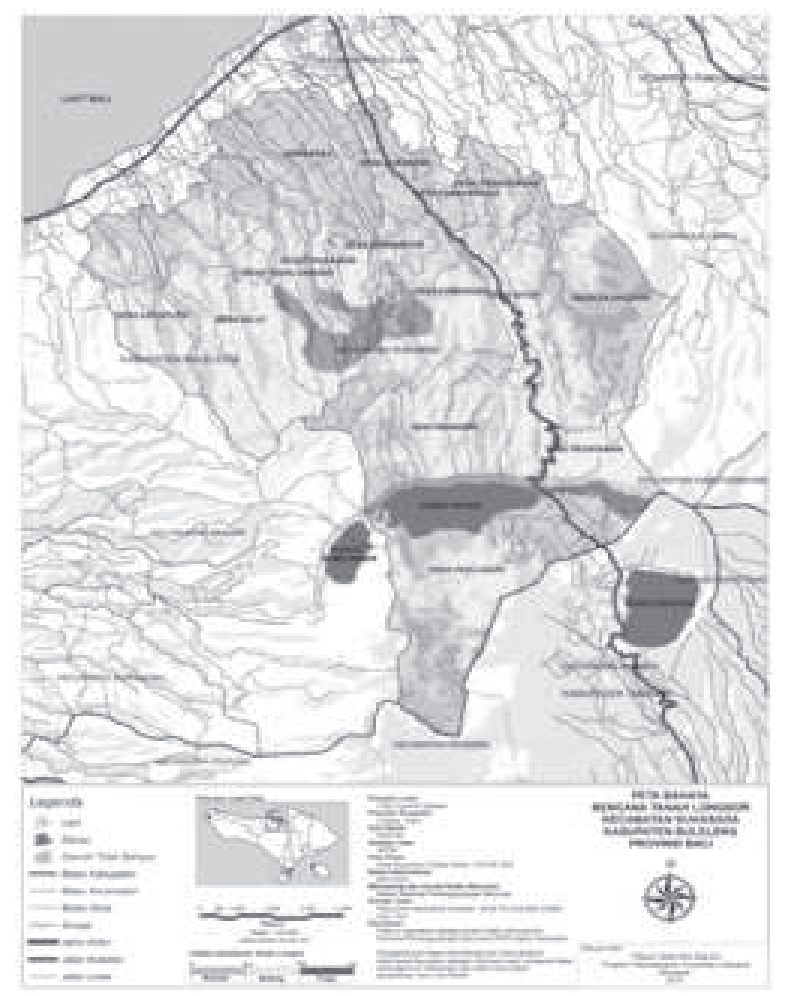

Gambar 1. Peta Bahaya Tanah Longsor Kecamatan Sukasada 
Tabel 5.Tingkat ancaman/bahaya bencana tanah longsor di Kecamatan Sukasada

\begin{tabular}{|c|c|c|c|c|c|c|c|c|}
\hline No & Desa & Populasi (jiwa) & Luas (ha) & $\begin{array}{c}\text { Bahaya } \\
\text { Rendah (ha) }\end{array}$ & $\begin{array}{c}\text { Bahaya } \\
\text { Sedang (ha) }\end{array}$ & $\begin{array}{l}\text { Bahaya } \\
\text { Tinggi (ha) }\end{array}$ & $\begin{array}{c}\text { Luas } \\
\text { Bahaya (ha) }\end{array}$ & $\begin{array}{l}\text { Persentase } \\
\text { Bahaya (\%) }\end{array}$ \\
\hline 1 & Pancasari & 4.609 & 2.794 & 719 & 771 & 47 & 1537 & 55,00 \\
\hline 2 & Wanagiri & 3.828 & 1.618 & 245 & 1.027 & 0 & 1272 & 78,62 \\
\hline 3 & Ambengan & 3.777 & 917 & 57 & 641 & 47 & 745 & 81,22 \\
\hline 4 & Gitgit & 3.731 & 359 & 24 & 239 & 0 & 263 & 73,19 \\
\hline 5 & Pegayaman & 5.811 & 1.600 & 245 & 107 & 100 & 1415 & 88,45 \\
\hline 6 & Silangjana & 2.486 & 1.224 & 642 & 402 & 0 & 1044 & 85,26 \\
\hline 7 & Pegadungan & 2.536 & 309 & 65 & 61 & 0 & 126 & 40,74 \\
\hline 8 & Padangbulia & 3.995 & 268 & 4 & 79 & 0 & 119 & 44,38 \\
\hline 9 & Sukasada & 6.603 & 446 & 102 & 52 & 0 & 154 & 34,52 \\
\hline 10 & Sambangan & 4.997 & 769 & 8 & 236 & 159 & 475 & 61,75 \\
\hline 11 & Panji & 9.207 & 1.011 & 111 & 270 & 97 & 478 & 47,30 \\
\hline 12 & Panji Anom & 5.752 & 912 & 84 & 300 & 106 & 490 & 53,72 \\
\hline 13 & Tegal Linggah & 6.678 & 935 & 94 & 441 & 165 & 700 & 74,86 \\
\hline
\end{tabular}

tinggal di wilayah bahaya bencana tanah longsor adalah 53.121 jiwa. Desa/kelurahan yang mempunyai tingkat bahaya terhadap bencana tanah longsor di Kecamatan Sukasada ditunjukkan pada Tabel 5 .

Terdapat 8 (delapan) desa/kelurahan yang mempunyai tingkat bahaya tinggi yaitu : Desa Tegal Linggah, Desa Sambangan, Desa Panji Anom, Desa Pegayaman, Desa Panji, Desa Ambengan, Desa Pancasari dan Desa Selat. Apabila dilihat dari luas wilayah yang mempunyai tingkat bahaya tinggi terhadap bencana tanah longsor di Kecamatan Sukasada mencapai 727 hektar. Desa Tegal Linggah merupakan desa dengan wilayah terluas dengan tingkat bahaya tinggi terjadinya bencana tanah longsor, yaitu seluas 165 hektar.

\subsection{Analisis kerentanan}

Nilai total kerentanan fisik di Kecamatan Sukasada adalah Rp. 384.900.000.000,-, yang terdiri dari nilai kerentanan rumah Rp. 124.950.000.000,dan nilai kerentanan fasilitas umum Rp. 259.950.000.000,00 dan Kecamatan Sukasada mempunyai tingkat kerentanan fisik sedang sampai tinggi.Desa Selat memiliki tingkat kerentanan fisik tertinggi senilai Rp. 45.874.000.000,- sedangkan Desa Pegadungan mempunyai tingkat kerentanan fisik terendah senilai Rp. 10.189.000.000,-.Skor kerentanan fisik bernilai sedang $(0,34$ sampai 0,66$)$ pada 3 (tiga) desa/kelurahan yaitu : Sukasada, Pegadungan dan Padangbulia.

Skor tingkat kerentanan sosial di Kecamatan Sukasada bernilai tinggi. Semua desa/kelurahan memiliki skor tinggi untuk kerentanan sosial. Hal ini disebabkan oleh tingginya kepadatan penduduk dan tingginya rasio jenis kelamin penduduk perempuan dibandingkan laki-laki. Sementara untuk rasio penduduk miskin, rasio penduduk cacat dan rasio umur rentan (bayi dan manula) rata-rata bernilai rendah. Kepadatan penduduk mempunyai bobot $60 \%$ yang mempengaruhi kerentanan sosial bencana tanah longsor. Seluruh desa/kelurahan di Kecamatan Sukasada kepadatan penduduk di atas $1.000 \mathrm{jiwa} / \mathrm{km}^{2}$ (kelas tinggi). Desa Selat mempunyai kepadatan penduduk tertinggi yaitu $6.593 \mathrm{jiwa} / \mathrm{km}^{2}$, Desa Pegadungan mempunyai kepadatan penduduk terendah yaitu $1.033 \mathrm{jiwa} / \mathrm{km}^{2}$.

Tingkat kerentanan ekonomi Kecamatan Sukasada berada di level tinggi. Hal ini disebabkan luas lahan produktif yang berada dalam daerah bahaya bencana tanah longsor mencapai 13.003,93 hektar. Jenis lahan produktif yang ada di Kecamatan Sukasada berupa hutan, kebun/perkebunan, sawah irigasi dan sawah tadah hujan. Seluruh lahan produktif di Kecamatan Sukasada termasuk ke dalam jenis lapangan usaha pertanian. Desa Pancasari memiliki luas lahan produktif terluas seluas 2.174,27 hektar sedangkan Desa Kayu Putih memiliki nilai lahan produktif tertinggi senilai $88.602,59$ juta rupiah.Pada tahun 2012 pendapatan domestik regional bruto (PDRB) Kecamatan Sukasada adalah 1.072.358,88 juta rupiah sedangkan nilai PDRB untuk lapangan usaha pertanian sebesar $307.605,78$ juta rupiah.

Kerentanan lingkungan Kecamatan Sukasada berkisar dari tingkat rendah sampai tinggi. Luas hutan yang berada dalam wilayah bahaya adalah 3.004,17 hektar sedangkan luas semak/belukar seluas 1.565,30. Desa Pancasari memiliki luas hutan terluas yaitu 1785.59 hektar sedangkan 8 (delapan) desa tidak mempunyai hutan. Terdapat 7 (tujuh) desa yang mempunyai kerentanan lingkungan tinggi yaitu Desa Pancasari, Desa Wanagiri, Desa Ambengan, Desa Pegayaman, Desa Sambangan, Desa Panji dan Desa Panji Anom.

Kecamatan Sukasada memiliki tingkat kerentanan sedang sampai tinggi. Skor kerentanan tertinggi sebesar 0,83 dimiliki oleh 4 desa, yaitu Desa Pancasari, Desa Pegayaman, Desa Panji dan Desa Panji Anom. Sedangkan Desa Padangbulia mempunyai skor terendah sebesar 0,66. Desa 
Pancasari dan Desa Pegayaman. Gambar 2. menunjukkan tingkat kerentanan terhadap bencana tanah longsor di Kecamatan Sukasada.Tabel 5.7 menunjukkan skor kerentanan pada Kecamatan Sukasada.

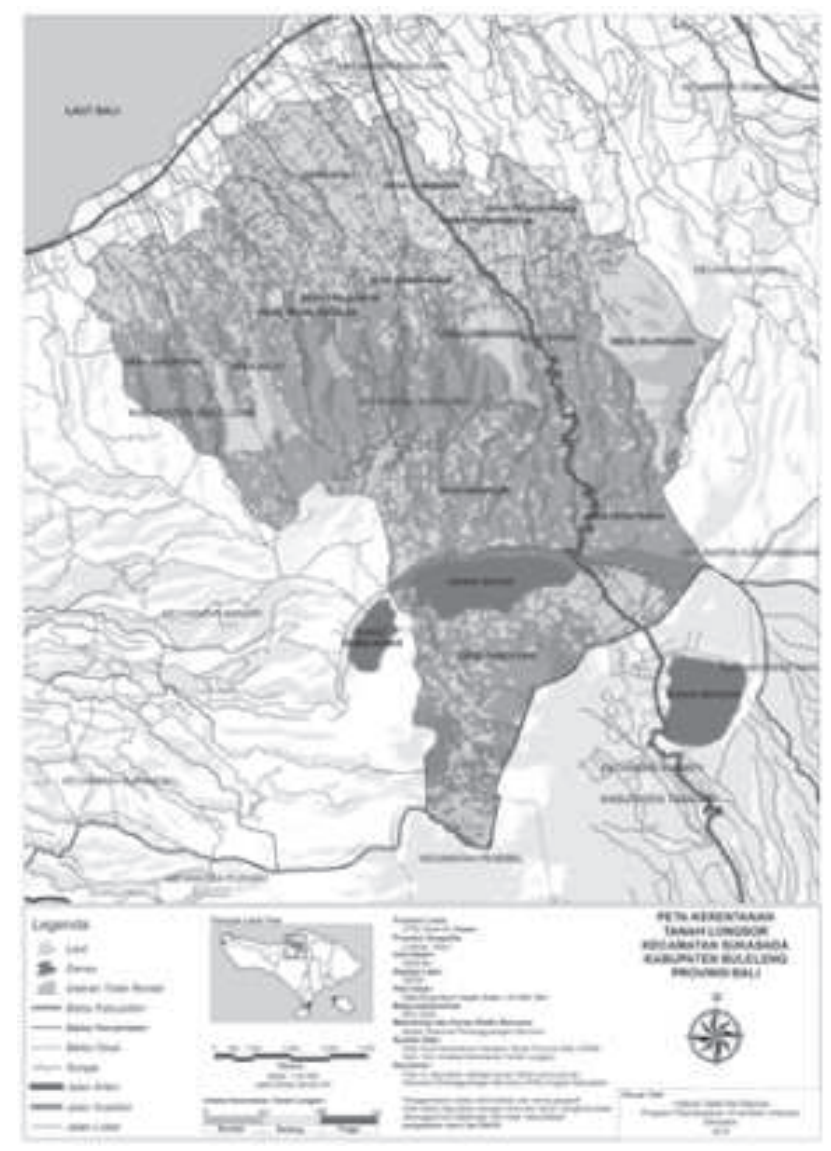

Gambar 2. Peta kerentanan Kecamatan Sukasada

\subsection{Analisis Kapasitas}

Untuk mendapatkan tingkat kapasitas penanggulangan bencana tanah longsor dapat dilakukan dengan mengunakan indek prioritas kapasitas daerah. Indeks indikator setiap prioritas ditentukan berdasarkan jawaban dari 88 pertanyaan yang diajukan.Hasil diskusi kelompok terfokus dengan Badan Penanggulangan Bencana Kabupaten Buleleng, Sekretaris Kecamatan Sukasada dan seluruh perbekel Kecamatan Sukasada diperoleh tingkat kapasitas Kecamatan Sukasada mempunyai indeks daerah 40,25 jika dikonversi kedalam tingkat kapasitas bernilai 0,2439 atau level rendah. Tabel 7.menunjukkan tingkat kapasitas penanggulangan bencana tanah longsor di Kecamatan Sukasada. Sedangkan Gambar 3.merupakan peta kapasitas penanggulangan bencana tanah longsor di Kecamatan Sukasada.

Penyebab dari rendahnya tingkat kapasitas Kecamatan Sukasada dalam penanggulangan bencana tanah longsor adalah rendahnya nilai pada Prioritas II, Prioritas III, Prioritas IV dan Prioritas V. Prioritas II bernilai rendah disebabkan belum adanya kajian risiko bencana di Kecamatan Sukasada dan tidak ada diseminasi peringatan dini bencana. Prioritas III bernilai rendah disebabkan oleh informasi bencana tidak dapat diakses oleh pemangku kepentingan, belum adanya riset mengenai kajian risiko bencana dan belum terbentuknya budaya tahan bencana. Prioritas IV bernilai rendah disebabkan oleh kurangnya usahausaha untuk mengurangi kerentanan terhadap bencana tanah longsor dan belum tersedianya prosedur penilaian dampak pembangunan terhadap

Tabel 6. Tingkat kerentanan bencana tanah longsor di Kecamatan Sukasada

\begin{tabular}{|c|c|c|c|c|c|c|}
\hline No & Desa & $\begin{array}{c}\text { Skor Kerentanan } \\
\text { Fisik }\end{array}$ & $\begin{array}{l}\text { Skor Kerentanan } \\
\text { Sosial }\end{array}$ & $\begin{array}{l}\text { Skor Kerentanan } \\
\text { Ekonomi }\end{array}$ & $\begin{array}{l}\text { Skor Kerentanan } \\
\text { Lingkungan }\end{array}$ & Skor Kerentanan \\
\hline 1 & Pancasari & 0,70 & 0,80 & 1,00 & 0,87 & 0,83 \\
\hline 2 & Wanagiri & 0,70 & 0,83 & 1,00 & 0,80 & 0,81 \\
\hline 3 & Ambengan & 0,70 & 0,80 & 1,00 & 0,90 & 0,83 \\
\hline 4 & Gitgit & 0,70 & 0,80 & 1,00 & 0,00 & 0,72 \\
\hline 5 & Pegayaman & 0,70 & 0,83 & 1,00 & 0,87 & 0,83 \\
\hline 6 & Silangjana & 0,70 & 0,83 & 1,00 & 0,10 & 0,73 \\
\hline 7 & Pegadungan & 0,57 & 0,80 & 1,00 & 0,07 & 0,71 \\
\hline 8 & Padangbulia & 0,43 & 0,80 & 1,00 & 0,03 & 0,66 \\
\hline 9 & Sukasada & 0,43 & 0,80 & 1,00 & 0,03 & 0,68 \\
\hline 10 & Sambangan & 0,70 & 0,80 & 1,00 & 0,90 & 0,83 \\
\hline 11 & Panji & 0,70 & 0,80 & 1,00 & 0,83 & 0,83 \\
\hline 12 & Panji Anom & 0,70 & 0,80 & 1,00 & 0,83 & 0,83 \\
\hline 13 & Tegal Linggah & 0,70 & 0,80 & 1,00 & 0,10 & 0,75 \\
\hline 14 & Selat & 0,70 & 0,83 & 1,00 & 0,10 & 0,76 \\
\hline \multirow[t]{2}{*}{15} & Kayuputih & 0,70 & 0,80 & 1,00 & 0,07 & 0,74 \\
\hline & Jumlah & 0,65 & 0,81 & 1,00 & 0,43 & 0,77 \\
\hline
\end{tabular}


risiko bencana. Priritas V bernilai rendah disebabkan oleh belum adanya pelatihan-pelatihan bencana terhadap penduduk serta tidak adanya prosedur selama masa tanggap darurat.

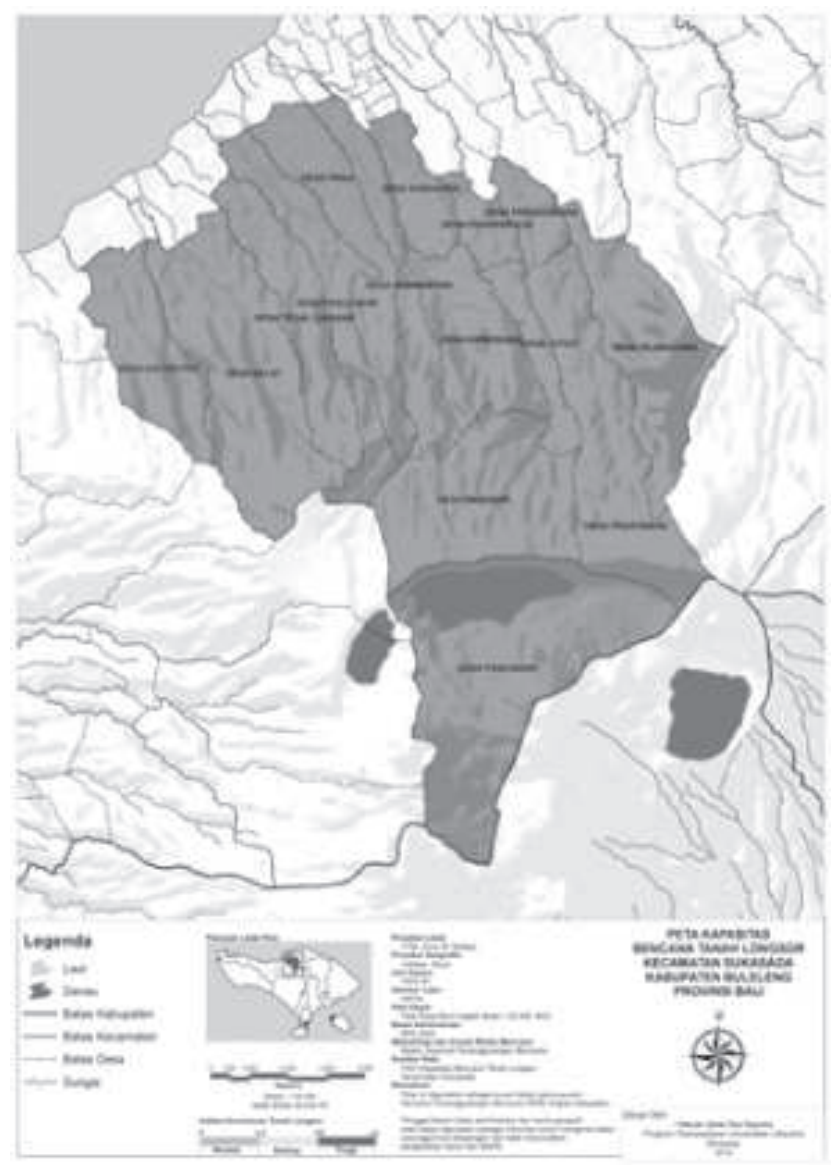

Gambar 3. Peta kapasitas Kecamatan Sukasada

Tabel 7. Tingkat kapasitas di Kecamatan Sukasada
Luas wilayah Kecamatan Sukasada yang mempunyai tingkat risiko tinggi terhadap bencana tanah longsor seluas 7.171 hektar yang ditempati oleh 32.269 jiwa. Sedangkan tingkat risiko sedang

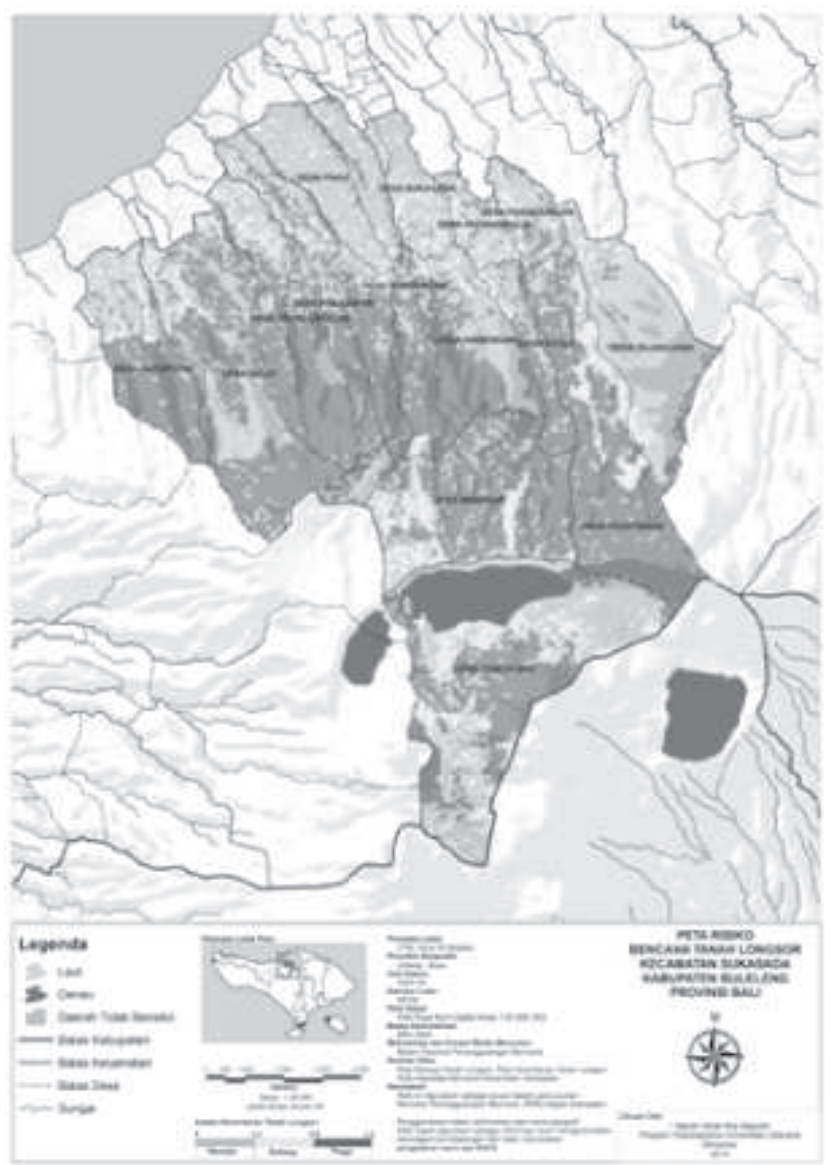

Gambar 4. Peta Risiko Kecamatan Sukasada

\begin{tabular}{llcc}
\hline NO & PRIORITAS & $\begin{array}{c}\text { TOTAL NILAI } \\
\text { PRIORITAS }\end{array}$ & $\begin{array}{c}\text { INDEKS } \\
\text { PRIORITAS }\end{array}$ \\
\hline 1 & $\begin{array}{l}\text { Memastikan bahwa pengurangan risiko bencana menjadi sebuah prioritas nasional dan lokal dengan } \\
\text { dasar kelembagaan yang kuat untuk pelaksanaannya }\end{array}$ & 56.25 & 3 \\
2 & $\begin{array}{l}\text { Mengidentifikasi, mengkaji dan memantau risiko bencana dan meningkatkan peringatan dini } \\
3\end{array}$ & Menggunakan pengetahuan, inovasi dan pendidikan untuk membangun suatu budaya & 32.5 \\
& keselamatan dan ketahanan disemua tingkat & 26.25 & 1 \\
4 & Mengurangi faktor-faktor risiko yang mendasar & 32.5 & 1 \\
5 & Memperkuat kesiapsiagaan terhadap bencana demi respon yang efektif di semua tingkat & 53.75 & 1 \\
\hline & TOTAL NILAI PRIORITAS & 40.25 & 2 \\
\hline
\end{tabular}

\subsection{Analisis Risiko}

Analisis risiko bencana tanah longsor mengkombinasikan faktor ancaman, faktor kerentanan dan faktor kapasitas. Penentuan tingkat risiko bencana tanah longsor dilakukan dengan menggunakan peta raster faktor bahaya, peta raster faktor kerentanan dan peta raster kapasitas. Gambar 4 menunjukkan tingkat risiko bencana tanah longsor di Kecamatan Sukasada. seluas 2.032 hektar dan ditempati oleh 9.665 jiwa. Total luas wilayah berisiko terhadap bencana tanah longsor di Kecamatan Sukasada adalah 9.203 hektar yang ditempati oleh 41.934 jiwa.Desa/kelurahan yang mempunyai tingkat risiko tinggi bencana tanah longsor di Kecamatan Sukasada ditunjukkan pada Tabel 8. 
Tabel 8. Tingkat risiko di Kecamatan Sukasada

\begin{tabular}{|c|c|c|c|c|c|c|c|}
\hline & Desa & $\begin{array}{c}\text { Risiko } \\
\text { Sedang (ha) }\end{array}$ & $\begin{array}{c}\text { Risiko } \\
\text { Tinggi (ha) }\end{array}$ & $\begin{array}{l}\text { Total Luas } \\
\text { Risiko (ha) }\end{array}$ & $\begin{array}{l}\text { Penduduk Risiko } \\
\text { Sedang (jiwa) }\end{array}$ & $\begin{array}{l}\text { Penduduk Risiko } \\
\text { Tinggi (jiwa) }\end{array}$ & $\begin{array}{l}\text { Total Penduduk } \\
\text { Berisiko (jiwa) }\end{array}$ \\
\hline 1 & Pancasari & 647 & 786 & 1.433 & 1.067 & 1.296 & 2.363 \\
\hline 2 & Wanagiri & 222 & 1.015 & 1.237 & 525 & 2.402 & 2.927 \\
\hline 3 & Ambengan & 48 & 471 & 519 & 198 & 1.939 & 2.137 \\
\hline 4 & Gitgit & 24 & 211 & 235 & 249 & 2.191 & 2.440 \\
\hline 5 & Pegayaman & 235 & 1.159 & 1.394 & 853 & 4.210 & 5.063 \\
\hline 6 & Silangjana & 109 & 137 & 246 & 221 & 278 & 499 \\
\hline 7 & Pegadungan & 56 & 55 & 111 & 460 & 451 & 911 \\
\hline 8 & Padangbulia & 84 & 21 & 105 & 1.252 & 313 & 1.565 \\
\hline 9 & Sukasada & 119 & 14 & 133 & 1.762 & 207 & 1.969 \\
\hline 10 & Sambangan & 64 & 369 & 433 & 416 & 2.397 & 2.813 \\
\hline 11 & Panji & 94 & 358 & 452 & 856 & 3.261 & 4.117 \\
\hline 12 & Panji Anom & 75 & 373 & 448 & 473 & 2.352 & 2.825 \\
\hline 13 & Tegal Linggah & 88 & 550 & 638 & 629 & 3.928 & 4.557 \\
\hline 14 & Selat & 89 & 1.151 & 1.240 & 356 & 4.599 & 4.955 \\
\hline \multirow[t]{2}{*}{15} & Kayuputih & 78 & 501 & 579 & 381 & 2.445 & 2.826 \\
\hline & Jumlah & 20.32 & 7.171 & 9203 & 9.665 & 32.269 & 41.934 \\
\hline
\end{tabular}

\subsection{Strategi Pengurangan Risiko}

Dari peta tingkat risiko bencana tanah longsor di Kecamatan Sukasada, dapat ditentukan strategi penanggulangan bencana tanah longsor, yaitu :

1. Melakukan pengelolaan kawasan yang memiliki kelerengan yang curam ataupun tanah yang tidak stabil.

2. Mengurangi kepadatan dan aktifitas penduduk yang bermukim di kawasan dengan tingkat risiko tinggi bencana tanah longsor.

3. Menentukan jalur dan tempat evakuasi jika terjadi bencana tanah longsor di Kecamatan Sukasada.

4. Melakukan mitigasi struktural dengan melaksanakan pembangunan yang bersifat fisik dilakukan pada desa/keluran yang tingkat risikonya tinggi.

5. Melakukan mitigasi non struktural seperti membuat aturan/regulasi yang mampu meengurangi risiko bencana tanah longsor. Dilakukan pada desa/keluran yang tingkat risikonya sedang

6. Adaptasi masyarakat dengan melaksanakan agroforestri yaitu penanaman campur antara tanaman pertanian dengan pepohonan berakar dalam.

Menurut Dubot and Watsala (2009), langkahlangkah yang dapat ditempuh untuk mengurangi risiko bencana tanah longsor :

1. Perumahan harus dibangun di luar dari ancaman bencana tanah longsor dan jauh dari pembabatan lereng.

2. Tanah penutup di lereng harus padat, semakin ke permukaan harus dilindungi dari erosi dan infiltrasi air. Diperlukan sebuah penutup permanen berupa tanah liat.
3. Vegetasi dan bronjong, kandang batu, dapat mengurangi erosi oleh air, dan harus memperbaiki drainase lereng, sehingga memperkuat stabilitas lereng. Kain sintetis seperti geo-textile bisa digunakan untuk memperkuat tanah.

4. Drainase yang luas serta pembuatan saluaran air atau parit untuk mencegah erosi dan aliran air permukaan.

5. Rekayasa struktur termasuk dengan cara Mechanically Stabilized Earth (MSE) dengan tujuan untuk mengurangi pergerakan tanah. Pembuatan penahan dinding dan soil nailing bertujuan untuk melindungi lereng, rock bolt atau jangkar digunakan untuk lereng yang berbatu.

\section{SIMPULAN DAN SARAN}

\subsection{Simpulan}

1. Ancaman bencana tanah longsor di Kecamatan Sukasada seluas 11.169 hektar atau 69,51\% dari luas wilayahnya. Tingkat ancaman tinggi seluas 727 hektar, tingkat ancaman sedang seluas 7.717 hektar dan tingkat ancaman rendah seluas 2.725 hektar.

2. Tingkat kerentanan bencana tanah longsor di Kecamatan Sukasada berkisar dari sedang sampai tinggi. Tingkat kerentanan tertinggi $(0,83)$ terdapat pada Desa Pancasari, Desa Pegayaman, Desa Panji dan Desa Panji Anom. Sedangkan tingkat kerentanan terendah $(0,66)$ di Desa Padangbulia.

3. Tingkat kapasitas daerah terhadap bencana tanah longsor Kecamatan Sukasada tergolong rendah. Dengan indeks ketahanan daerah 40,25 atau tingkat kapasitasnya 0,2349. 
4. Tingkat risiko bencana tanah longsor di Kecamatan Sukasada tergolong sedang sampai tinggi. Daerah dengan tingkat risiko sedang seluas 2.032 hektar dan tingkat risiko tinggi seluas 7171 hektar.

\subsection{Saran}

1. Perlu adanya pengawasan dan penegakkan aturan/regulasi pemanfaatan lahan pada daerah bahaya bencana tanah longsor untuk mengurangi meluasnya daerah bahaya dan mengurangi tingkat kerentanan.

2. Peningkatan kapasitas bencana harus dilakukan guna mengurangi tingkat risiko bencana tanah longsor mengingat tingkat risiko bencana tanah longsordi Kecamatan Sukasada tergolong sedangtinggi.

3. Mitigasi non struktural dilaksakan pada daerah tingkat risiko sedang sedangkan mitigasi struktural dilakukan pada daerah tingkat risiko tinggi.

4. Menyediakan informasi yang relevan dan dapat diakses oleh semua pemangku kepentingan, menyiapkan sistem peringatan dini bencana tanah longsor, menjalin partisipasi dan pemberdayaan komunitas bencana serta melakukan simulasi bencana tanah longsor kepada masyarakat.

5. Untuk penelitian selanjutnya diharapkan dapat memperoleh dan menggunakan data sebaran rumah dan fasilitas umum.

\section{DAFTAR PUSTAKA}

Bappeda Bali dan PPLH UNUD. 2006. Studi Identifikasi Potensi Bencana Alam DiProvinsi Bali,Laporan Penelitian, BadanPerencanaan Pembangunan Daerah Provinsi Bali dan Pusat Penelitian Lingkungan Hidup Lembaga Penelitian Universitas Udayana, Denpasar.

BPBD Bali. 2014. Laporan Bencana Bulanan Provinsi Bali. Badan Penanggulangan Bencana Daerah Provinsi Bali.

BNPB. 2012. Pedoman Umum Pengkajian Risiko Bencana. Peraturan Kepala Badan Nasional Penanggulangan Bencana No. 2 Tahun 2012.

. 2012. Panduan Penilaian Kapasitas Daerah Dalam Penanggulangan Bencana. Peraturan Kepala Badan Nasional Penanggulangan Bencana No. 3 Tahun 2012.

Departemen ESDM. 2009. Peta Zona Kerentanan Gerakan Tanah Provinsi Bali. Pusat Vulkanologi dan Mitigasi Bencana Geologi.

Dinata, I.W.H.I., Treman, I.W. dan Suratha, I.K. 2013. Pemetaan Daerah Rawan Bencana Longsor di Kecamatan Sukasada. Jurnal Jurusan Pendidikan Geografi Vol. 3 No. 1: 1-10

Dubot, Alice and Jayamanna, Watsala. 2009. Safer Cities 26 : Using Risk Assessments to Reduce Landslide Risk. Asian Disaster Preparedness Center/ADPC. Bangkok.

Subowo, E. 2003. Pengenalan Gerakan Tanah. Pusat Volkanologi dan Mitigasi Bencana Geologi, Departemen Energi dan Sumber Daya Mineral. Bandung.

Undang-Undang Republik Indonesia Nomor 24 Tahun 2007 tentang Penanggulangan Bencana. 